\title{
Efektifitas Multimedia Berbasis Potensi Lokal Untuk Meningkatkan Keterampilan Mengajar Mahasiswa Pada Mata Kuliah Strategi Pembelajaran Kimia
}

\author{
Khaeruman $^{1}$, Siti Nurhidayati ${ }^{2}$ \\ ${ }^{1}$ Pendidikan Kimia, ${ }^{2}$ Pendidikan Biologi \\ FSTT, Universitas Pendidikan Mandalika (UNDIKMA) Mataram \\ Email: khaeruman81@gmail.com, sitinurhidayati328@gmail.com
}

\begin{abstract}
Abstrak. Keterampilan mengajar mahasiswa perlu ditingkatkan, terutama dengan kondisi perkuliahan dimasa pandemic, dimana kuliah dilakukan secara daring tanpa tatap muka. Pada Mata Kuliah Stragegi Pembelajaran Kimia mahasiswa dituntut untuk memahami berbagai macam strategi yang nantinya bisa diamplikasikan di sekolah, mengadopsi dan memodifikasi atau bahkan mengembangkan strategi sesuai karakteristik materi yang dibahas dan keadaan atau persoalan yang terjadi di lingkungan sekitar menggunakan multimedia berbasis potensi lokal. Penelitian ini berupa deskriptif kualitatif. Ada 6 (enam) indikator yang diukur yaitu: 1). Keterampilan bertanya, 2). Keterampilan menjelaskan, 3). Keterampilan memberi penguatan, 4). Keterampilan mengajar kelompok kecil, 5). Keterampilan membimbing diskusi. 6). Keterampilan membuka dan menutup pembelajaran. Instrumen yang digunakan adalah lembar observasi keterampilan mengajar. Penskoran keterampilan mengajar mahasiswa menggunakan skor 1 untuk indikator yang nampak, dan skor 0 untuk indikator yang tidak Nampak, kemudian dianalisis secara deskriptif presentase. Hasil penelitian ini menunjukkan bahwa pada putaran I pembelajaran diperoleh bahwa keterampilan bertanya mahasiswa 65\% (sedang), keterampilan menjelaskan 56\% (rendah), keterampilan memberi penguatan 66\% (sedang), keterampilan mengajar kelompok kecil 56\% (rendah), keterampilan membimbing diskusi 53\% (rendah), keterampilan membuka dan menutup pembelajaran berada pada 58\% (rendah), dengan rata-rata klasikal sebesar 59\% (rendah). Pada putaran II pembelajaran diperoleh bahwa ada peningkatan keterampilan mengajar mahasiswa diantaranya keterampilan bertanya mahasiswa 88\% (sangat tinggi), keterampilan menjelaskan $72 \%$ (sedang), keterampilan memberi penguatan $85 \%$ (tinggi), keterampilan mengajar kelompok kecil 75\% (sedang), keterampilan membimbing diskusi 69\% (sedang), keterampilan membuka dan menutup pembelajaran $73 \%$ (sedang), dengan rata-rata klasikal sebesar $77 \%$ (tinggi). Untuk itu dapat disimpulkan bahwa penggunaan multimedia berbasis potensi lokal efektif untuk meningkatkan keterampilan mengajar mahasiswa.
\end{abstract}

Kata Kunci: Multimedia; Potensi_Lokal; Keterampilan_Mengajar; Strategi_Pembelajaran.

\section{PENDAHULUAN}

Strategi pembelajaran kimia merupakan salah satu mata kuliah yang harus ditempuh mahasiswa Pendidikan kimia semester VI, agar mahasiswa memahami berbagai macam strategi yang nantinya bisa diamplikasikan di sekolah, mengadopsi dan memodifikasi atau bahkan mengembangkan strategi sesuai karakteristik materi yang dibahas dan keadaan atau persoalan yang terjadi di lingkungan sekitar. Pola perkuliahan strategi pembelajaran kimia juga berubah seiring dengan merebaknya pandemic covid 19, yaitu perkuliahan dalam bentuk daring, dimana mahasiswa belajar dari rumahnya masing-masing. Melalui pembelajaran 
daring mahasiswa bisa mengakses materi dan berinteraksi dengan mahasiswa lain maupun dosen secara online untuk mendapatkan pengetahuan atau wawasan, serta mendapat pengalaman belajar.

Pada perkulihan daring strategi pembelajaran kimia mengalami kendala misalnya, mahasiswa tersebar di berbagai daerah, dimana ada daerah-daerah tidak terjangkau sinyal. Untuk itu digunakan multimedia berbasis potensi lokal agar mahasiswa bisa menyesuaikan strategi yang cocok untuk diterapkan di lingkungan sekitarnya, dengan mengeksplorasi potensi lokal sekitar untuk mendukung pembelajaran serta menggunakan multimedia yang sesuai dengan kebutuhan dan sarana maupun prasarana yang tersedia, selain itu peserta didik dapat mengkases/memutar ulang materi yang belum dipahami.

Multimedia berasal dari kata multi dan media, dimana multi berarti banyak dan media adalah sarana/alat/perantara komunikasi untuk menyampaikan pesan (materi) yang dapat merangsang minat peserta didik untuk belajar (Khaeruman dan Nurhidayati, 2016). Peserta didik dapat membentuk sendiri pengetahuannya berdasarkan hasil pengamatan mereka dari multimedia berupa video atau animasi yang tentunya dapat berpengaruh pada pemahaman peserta didik (Suriyani, dkk, 2018).

Multimedia adalah penggabungan berbagai media misalnya gambar, suara, teks, animasi, audia, video, dan lain-lain. Multimedia juga berpengaruh pada keterampilan proses sains, keterampilan sains dan keterampilan generik sains mahasiswa (Khery dan Khaeruman, 2017); (Khaeruman, dkk, 2018); (Mashami dan Khaeruman, 2017); selain itu dapat meningkatkan kemampuan berpikir kritis mahasiswa (Isnaneny, dkk, 2018).
Multimedia yang digunakan adalah multimedia berbasis potensi lokal, dimana mahasiswa melakukan kuliah secara daring dari rumah masing masing, dan bisa menganalisis berbagai persoalan di lingkungan sekitar terkait dengan pembelajaran kimia, kemudian disajikan dalam bentuk multimedia. Mahasiswa menerapkan strategi pembelajaran kimia secara langsung melalui pembelajaran daring, dimana ada mahasiswa yang berfungsi sebagai guru model dan ada yang berfungsi sebagai peserta didik menggunakan multimedia berbasis potensi lokal.

Penggunaan potensi lokal memudahkan mahasiswa memahami konsep yang dipelajari (Nurhidayati dan Khaeruman, 2020), karena mengaitkan langsung dengan persolahan yang ada di tengah masyarakat, sehingga apa yang telah dipelajari menjadi lebih bermakna (Nurhidayati dan Khaeruman, 2017). Selain itu mahasiswa akan lebih hormat pada lingkungan, misalnya memaksimalkan potensi lokal di sekitar sebagai bahan belajar untuk mencapai tujuan pembelajaran (Nurhidayati dan Khaeruman, 2019).

Melalui perkuliahan strategi pembelajaran kimia menggunakan multimedia berbasis potensi lokal, diharapkan mahasiswa dapat meningkatkan pemahaman dan keterampilan mengajarnya. Keterampilan mengajar adalah keterampilan atau kecakapan standar yang harus dimiliki oleh seorang guru atau pendidik atau pengajar, misalnya; keterampilan bertanya, menjelaskan, penguatan, menvariasikan, membuka dan menutup pembelajaran, pengelolaan kelas, mengajar kelompok kecil, membimbing diskusi.

Adapun keterampilan mengajar tersebut diantaranya keterampilan menyusun RPP, keterampilan memberi penguatan, keterampilan bertanya, keterampilan 
menggunakan variasi, keterampilan menjelaskan, keterampilan membuka dan menutup pelajaran, keterampilan mengajar kelompok kecil dan perseorangan, keterampilan mengelola kelas, dan keterampilan membimbing diskusi kelompok (Hasibuan dan Moejiono, 2010).

Selain itu mempersiapkan siswa belajar, penerapan konsep apersepsi, penguasaan materi, penggunaan metode/media, penggunaan LKS, gaya menulis dan mutu tulisan, gaya berkomunikasi dan bahasa lisan serta rangkuman atau penguatan juga merupakan keterampilan yang perlu dikuasai oleh seorang pengajar (Asiah, 2016).

\section{METODE}

Penelitian ini merupakan penelitian deskriptif kualitatif dengan tujuan untuk mendekripikan bagaimana keterampilan mengajar Mahasiswa Pendidikan Kimia menggunakan multimedia berbasis potensi lokal pada mata kuliah strategi pembelajaran kimia.

Data keterampilan mengajar mahasiswa pada mata kuliah strategi diperoleh menggunakan instrumen lembar observasi, dimana masing-masing mahasiswa menjadi guru model sedangkan mahasiswa lainnya berperan sebagai peserta didik dalam pembelajaran menggunakan multimedia berbasis potensi lokal. Setiap mahasiswa memilih strategi yang berbeda dan memperoleh dua kali kesempatan untuk mengajar secara daring.

Dalam penelitian ini ada 6 (enam) indikator yang diukur dalam penelitian ini adalah 1). keterampilan bertanya, 2). keterampilan menjelaskan, 3). keterampilan memberi penguatan, 4). Keterampilan mengajar kelompok kecil, 5). keterampilan membimbing diskusi. 6). keterampilan membuka dan menutup pembelajaran,
Penskoran keterampilan mengajar mahasiswa menggunakan skor 1 untuk indicator yang nampak, dan skor 0 untuk indicator yang tidak nampak. Hasil penjumlahan skor kemudian dianalisis secara deskriptif presentase menggunakan rumus:

Persentase $=\underline{\text { Skor yang diperoleh }} \times 100 \%$ Skor maksimal

Data hasil penghitungan keterampilan mahasiswa berupa nilai persentasi yang diperoleh tersebut kemudian dikonversikan menggunakan pedoman berikut ini.

Tabel 1. Pedoman Penilaian Keterampilan Mengajar

\begin{tabular}{|l|c|c|}
\hline No. & $\begin{array}{l}\text { Persentase } \\
\text { Keterampilan }\end{array}$ & Kriteria \\
\hline 1 & $86-100$ & Sangat tinggi \\
\hline 2 & $76-85$ & Tinggi \\
\hline 3 & $60-75$ & Sedang \\
\hline 4 & $55-59$ & Rendah \\
\hline 5 & $<55$ & Sangat rendah \\
\hline
\end{tabular}

HASIL DAN PEMBAHASAN

Mahasiswa Pendidikan Kimia terlebih dahulu mengkaji berbagai strategi dalam pembelajaran kimia secara daring, kemudian masing-masing mahasiswa memilih strategi yang berbeda dan materi yang berbeda. Strategi tersebut dipadukan dengan berbagai potensi lokal terkait yang ada di lingkungan mahasiswa tersebut yang mendukung materi kimia yang akan diajarkan, kemudian diaplikasikan dalam pembelajaran menggunakan multimedia.

Mahasiswa Pendidikan Kimia secara bergantian menjadi guru model, untuk mengaplikasikan strategi dan materi kimia yang telah dipilih, kemudian mahasiswa lainnya berperan sebagai peserta didik menggunakan multimedia berbasis potensi lokal, hal ini untuk melatih agar mahasiswa 
Jurnal Ilmu Sosial dan Pendidikan

http://ejournal.mandalanursa.org/index.php/JISIP/index

Terakreditasi Peringkat 5 (No. SK: 85/M/KPT/2020)
Vol. 5. No. 2 Maret 2021

p-ISSN: 2598-9944 e- ISSN: 2656-6753 memiliki keterampilan mengajar menggunakan berbagai strategi.

Data keterampilan mengajar mahasiswa berupa keterampilan bertanya, keterampilan menjelaskan, keterampilan memberi penguatan, keterampilan mengajar kelompok kecil, keterampilan membimbing diskusi, dan keterampilan membuka dan menutup pembelajaran, Data keterampilan mengajar mahasiswa disajikan pada Tabel 2 berikut.

Tabel 2. Data keterampilan mengajar mahasiswa pada Mata Kuliah Strategi Pembelajaran Kimia.

\begin{tabular}{|l|c|c|c|c|}
\hline \multirow{2}{*}{ Indikator } & \multicolumn{2}{|c|}{ Putaran I } & \multicolumn{2}{c|}{ Putaran II } \\
\cline { 2 - 5 } & $\%$ & Kategori & $\%$ & Kategori \\
\hline $\begin{array}{l}\text { Keterampilan } \\
\text { bertanya }\end{array}$ & 65 & Sedang & 88 & $\begin{array}{c}\text { Sangat } \\
\text { Tinggi }\end{array}$ \\
\hline $\begin{array}{l}\text { Keterampilan } \\
\text { menjelaskan }\end{array}$ & 56 & Rendah & 72 & Sedang \\
\hline $\begin{array}{l}\text { keterampilan } \\
\text { memberi } \\
\text { penguatan }\end{array}$ & 66 & Sedang & 85 & Tinggi \\
\hline $\begin{array}{l}\text { Keterampilan } \\
\text { mengajar } \\
\text { kelompok } \\
\text { kecil }\end{array}$ & 56 & Rendah & 75 & Sedang \\
\hline $\begin{array}{l}\text { Keterampilan } \\
\text { membimbing } \\
\text { diskusi }\end{array}$ & 53 & Rendah & 69 & Sedang \\
\hline $\begin{array}{l}\text { Keterampilan } \\
\text { membuka dan } \\
\text { menutup } \\
\text { pembelajaran }\end{array}$ & 58 & Rendah & 73 & Sedang \\
\hline $\begin{array}{l}\text { Persentase } \\
\text { Klasikal }\end{array}$ & 59 & Rendah & 77 & Tinggi \\
\hline
\end{tabular}

Berdasarkan Tabel 2, diperoleh bahwa pada putaran pertama pembelajaran diperoleh bahwa keterampilan bertanya mahasiswa berada pada 65\% dengan kategori sedang, keterampilan menjelaskan berada pada 56\% dengan kategori rendah, keterampilan memberi penguatan berada pada $66 \%$ dengan kategori sedang, keterampilan mengajar kelompok kecil berada pada 56\% dengan kategori rendah, keterampilan membimbing diskusi berada pada 53\% dengan kategori rendah, keterampilan membuka dan menutup pembelajaran berada pada 58\% dengan kategori rendah, sehingga keterampilan mengajar mahasiswa pada putaran pertama mencapai rata-rata persentase klasikal sebesar 59\% dengan kategori rendah.

Pada putaran kedua pembelajaran diperoleh bahwa ada peningkatan keterampilan mengajar mahasiswa diantaranya keterampilan bertanya mahasiswa berada pada $88 \%$ dengan kategori sangat tinggi, keterampilan menjelaskan mencapai $72 \%$ dengan kategori sedang, keterampilan memberi penguatan mencapai $85 \%$ dengan kategori tinggi, keterampilan mengajar kelompok kecil mencapai $75 \%$ dengan kategori sedang, keterampilan membimbing diskusi mencapai $69 \%$ dengan kategori sedang, keterampilan membuka dan menutup pembelajaran mencapai $73 \%$ dengan kategori sedang, sehingga keterampilan mengajar mahasiswa pada putaran kedua mencapai rata-rata persentase klasikal sebesar $77 \%$ dengan kategori tinggi.

Penggunaan multimedia berbasis potensi lokal efektif untuk meningkatkan keterampilan mengajar mahasiswa, hal ini terlihat dari keterampilan mengajar mahasiswa pada putaran pertama mencapai rata-rata persentase klasikal sebesar 59\% dengan kategori rendah dan meningkat pada putaran kedua dimana keterampilan mengajar mahasiswa mencapai rata-rata persentase klasikal sebesar $77 \%$ dengan kategori tinggi.

Hal ini karena penggunaan multimedia berbasis potensi lokal sangat membantu guru dalam proses pembelajaran misalnya guru lebih mudah membangkitkann minat dan motivasi peserta didik, guru juga dapat memunculkan pertanyaan setelah penyajian materi 
menggunakan multimedia yang dikaitkan dengan potensi lokal yang ada di lingkungan sekitar, guru dapat menjelaskan materi menggunakan bahasa yang sederhana diperkuat oleh ilustrasi menggunakan multimedia serta dikaitkan dengan persoalan yang ada di tengah masyarakat, membimbing diskusi kecil dengan membagi kelompok kecil kemudian disajikan materi dengan multimedia yang berbeda dan menganalisis masalah yang berbeda. Serta mereview kembali materi baik secara langsung atau menggunakan multimedia, sehingga peserta didik lebih mudah memahami apa yang dipelajari.

Hasil penelitian ini sejalan dengan penelitian Mulyatun (2014) yaitu Keterampilan dasar mengajar Mahasiswa Tadris Kimia berupa 1) Keterampilan bertanya, 2) Keterampilan memberi penguatan, 3) Keterampilan mengadakan variasi, 4) Keterampilan menjelaskan, 5) Keterampilan membuka dan menutup pelajaran, 6) Keterampilan membimbing diskusi kelompok kecil, 7) Keterampilan mengelola kelas, 8) Keterampilan mengajar kelompok kecil dan perorangan secara keseluruhan adalah baik. Ambarawati (2016), keterampilan mengajar mahasiswa calon guru matematika IKIP Budi Utomo berada pada kategori sangat baik. Asiah, (2016), kemampuan mahasiswa PPL Fakultas Tarbiyah dan Keguruan UIN ArRaniry Banda Aceh dalam menerapkan keterampilan dasar mengajar pada kegiatan PPKPM secara keseluruhan dapat dikategorikan baik. Agustina dan Saputra, (2017), skor capaian keterampilan dasar mengajar pada matakuliah microteaching mengalami peningkatan pada kedua tampilan latihan mengajar.

$$
\text { Selain dapat meningkatkan }
$$

keterampilan mengajar, penggunaan multimedia berbasis potensi lokal dalam pembelajaran juga dapat meningkatkan pemahaman dan kemampuan berpikir kritis mahasiswa (Nurhidayati dan Khaeruman, 2020), misalnya pemanfaatkan potensi lokal berupa zat warna pada tumbuhan yang ada di lingkungan sekitar sebagai indikator asam basa pada pembelajaran kimia seperti: kunyit, pandan, kembang sepatu, jeruk, kubis ungu, belimbing, lidah buaya, kulit manggis yang sangat mudah diperoleh di lingkungan sekitar (Nurhidayati, dkk, 2019), kemudian dapat dipraktikumkan secara langsung atau disimulasikan menggunakan multimedia, sehingga tujuan pembelajaran yang direncanakan dapat tercapai.

Data keterampilan mengajar mahasiswa ini hanya mendeskripsikan indikator keterampilan mengajar mahasiswa yang nampak dan tidak nampak, kemudian dikompersikan menggunakan persentase, bukan mengukur kualitas keterampilan mengajar mahasiswa, karena Mata Kuliah Strategi Pembelajaran merupakan pembelajaran awal bagi mahasiswa mengenai bagaimana cara mengajar, yang nantinya akan dilanjutkan dengan Mata Kuliah Microteaching, dimana mahasiswa juga langsung mempraktikkan cara mengajar dan diukur bagaimana kualitas keterampilan mengajarnya, sehingga mahasiswa lebih mudah ketika menerapkannya kembali berbagai strategi yang telah dipelajarinya di sekolah dalam bentuk Pengenalan Lapangan Persekolahan (PLP) atau yang dulu dikenal dengan Praktik Pengalaman Lapangan (PPL).

\section{KESIMPULAN}

Adapun yang dapat disimpulakn dari penelitian ini adalah: Penggunaan multimedia berbasis potensi lokal efektif untuk meningkatkan keterampilan mengajar mahasiswa, hal ini terlihat dari keterampilan mengajar mahasiswa pada putaran pertama mencapai rata-rata persentase klasikal sebesar 59\% dengan kategori rendah dan 
meningkat pada putaran kedua dimana keterampilan mengajar mahasiswa mencapai rata-rata persentase klasikal sebesar $77 \%$ dengan kategori tinggi.

\section{DAFTAR PUSTAKA}

Agustina, P., dan Saputra, A. (2017), Profil Keterampilan Dasar Mengajar Mahasiswa Calon Guru Biologi pada Matakuliah Microteaching. JURNAL BIOEDUKATIKA Vol. V No. 1: 18 28.

Ambarawati, M. 2016. Analisis Keterampilan Mengajar Calon Guru Pendidikan Matematika Pada Mata Kuliah Micro Teaching. Jurnal Pedagogia. Volume. 5, No. 1, hal: 8190.

Asiah, N. 2016. Analisis Keterampilan Dasar Mengajar Mahasiswa Ppl Fakultas Tarbiyah Dan Keguruan Uin Ar-Ranirybanda Aceh (Studi Deskriptif Kegiatan Ppkpm). Prosiding Seminar Nasional Biotik 2016, ISBN: 978-602-18962-9-7, Hal: 367-374.

Hasibuan dan Moedjiono. 2010. Proses Belajar Mengajar. Bandung: Remaja Rosdakarya.

Isnaneny, F.Y., Sajidan, dan Masykuri, M. (2018). Pengembangan Multimedia Interaktif Berbasis Problem Based Learning (Pbl) Untuk Meningkatkan Kemampuan Berpikir Kritis Mahasiswa Program Studi Pendidikan Biologi UMS Pada Materi Sistem Gerak Manusia. Jurnal Inkuiri, Vol. 7, No. 1, 2018 (hal 111-120).

Khaeruman., Azizah, R., dan Nurhidayati, S. (2018). Pengaruh Multimedia Interaktif Terhadap Keterampilan Generik Sains Dan Pemahaman Konsep Elektrokimia Siswa. JISIP. 2 (1): 329-337.

Jurnal Ilmu Sosial dan Pendidikan
Khery, Y., dan Khaeruman. (2017). Pengaruh Context-Rich Problems Berbentuk Multimedia Interaktif Terhadap Keterampilan Proses Sains, Sikap Ilmiah, Dan Pemahaman Konsep

Mashami, R.A., dan Khaeruman. (2020). Pengembangan Multimedia Interaktif Kimia Berbasis PBL (Problem Based Learning) untuk Meningkatkan Keterampilan Generik Sains Siswa. Hydrogen: Jurnal Kependidikan Kimia. Vol. 8, No.2. hal: 85-96.

Mulyatun. (2014). Analisis Keterampilan Dasar Mengajar Mahasiswa Calon Guru Kimia (Studi Pada Praktik Pengalaman Lapangan Mahasiswa Tadris Kimia). Jurnal PHENOMENON, Volume 4 Nomor 1: 79-90.

Nurhidayati, S., dan Khaeruman. (2016). Trik-trik Mengajar. Penerbit: Lembaga Penelitian dan Pendidikan (LPP) Mandala.

Nurhidayati, S., dan Khaeruman. (2017). Pengembangan Bahan Ajar Bioteknologi Berbasis Potensi Lokal. JUPE. 2 (2): 87-91.

Nurhidayati, S. (2019). Pengintegrasian Potensi Lokal Pada Mata Kuliah Pendidikan Karakter Untuk Meningkatkan Hasil Belajar Dan Rasa Hormat Mahasiswa Terhadap Lingkungan. JUPE. 4 (4): 257-260.

Nurhidayati, S., Khaeruman, dan Mashami, R.A. (2019). Pengembangan Lks Berbasis Potensi Lokal Untuk Meningkatkan Keterampilan Kerja Ilmiah Dan Pemahaman Konsep Biologi Dan Kimia Siswa. JUPE: Jurnal Pendidikan Mandala. Vol. 4. No. 5: 7-12.

Nurhidayati, S., dan Khaeruman. (2020). Efektifitas Multimedia Dan Potensi Lokal Untuk Meningkatkan 
Keterampilan Berpikir Kritis

Mahasiswa Pada Mata Kuliah

Perkembangan Peserta Didik. Jurnal

Ilmiah IKIP Mataram. Vol. 7. No.1. Maret 2020: 115-118.

Nurhidayati, S., dan Khaeruman. (2021). Pengintegrasian Potensi Lokal Pada Mata Kuliah Inovasi Pembelajaran Untuk Meningkatkan Pemahaman Konsep Mahasiswa. Jurnal Ilmu Sosial dan Pendidikan. Vol. 5. No. 1: 309-312.

Suriyani, N., Khaeruman., dan Pahriah. (2018). Pengembangan Multimedia Interaktif Berbasis Kontekstual terhadap Pemahaman Konsep Pada Materi Asam Basa Untuk SMA. Prosiding Seminar Nasional. Lembaga Penelitian dan Pendidikan (LPP) Mandala: 558-566. 